\title{
THE JAMAICA LETTER AND ITS INTELLECTUAL GENEALOGY
}

A Carta da Jamaica e sua genealogia intelectual
Germán A. de la

\section{REZA}

Universidad Autónoma Metropolitana - UAN germandelareza@hotmail.com

\section{ABSTRACT}

One of the fundamental objectives of The Jamaica Letter is the reflection on the features that should have the international order after the fall of the Spanish Empire. For its organization, Simon Bolivar appeals to the amphictyonic assemblies of classical Greece and invokes the Pan-European project of the Abbe Saint Pierre. This article traces the documentary sources from which Bolivar derives his notion of confederal union and inspires the unions treaties from 1822 to 1826 .

Palavras-chave: Simon Bolivar; Latin American Independence; Confederation; Latin American Integration; Amphictyonic League.

\begin{abstract}
RESUMO
Um dos objetivos da Carta da Jamaica é a reflexão sobre as características da ordem americana e internacional, após a desaparição do Império espanhol. Para a sua organização, Simon Bolivar apela às ligas anfictiônicas da Grécia clássica e invoca o projeto Pan-Europeu do Abade de Saint Pierre. Este artigo traça as fontes documentais que nutrem seu conceito confederal e os primeiros tratados da união hispano-americana de 1822 a 1826.
\end{abstract}

Keywords: Simon Bolivar; Independência da América; Confederação; Integração latinoamericana; Liga anfictiônica. 


\section{Introduction}

n November 2014, the governments of Venezuela and Ecuador announced at a press conference the discovery of the original manuscript of the Jamaica Letter, written by the then-secretary of Simón Bolívar, Pedro Briceño Méndez. Prior to this finding, there were two older versions of the essay published in Kingston on September 6, 1815: an English draft, preserved in the General Archive of the Nation of Bogotá, and the Spanish text published in 1833 by Cristóbal de Mendoza and Francisco Yanes (1833). ${ }^{1}$ This discovery and the Letter's bicentennial celebrations have renewed attention to the 17-page document, which is perhaps the most influential writing of the independence process, as reflected by an unusual number of studies. This article aims to illuminate an aspect that, although essential for independence unionism, remains unexplored in those studies: the origins and meanings of Bolivar's amphictyonic conception and his imprint on the objectives and characteristics of the Congress of Panama.

The most apparent objective of the Jamaica Letter is to explain the failure of the first Venezuelan independence to an enigmatic English observer, Henry Cullen; the underlying motive is to reflect on the American order that is about to rise from the ashes of the Spanish Empire. Although the moment in time is still unfavorable for the patriot movement, Bolivar has no doubt that the former Spanish America will achieve its emancipation. However, this goal will be attained not by one, but by several independent countries. The clash of both tendencies, independence and the atomization of colony sections, and its likely effect, the appearance of several small states, lead him to propose a confederal union similar to the league of Greek states in the Isthmus of Corinth. Bolivar points to Panama as the headquarters of the "august congress", where an assembly of representatives will meet. This assembly will be backed by a confederate army, a court of arbitration to settle internal and external conflicts, and a commercial code.

Where does Bolivar nourish the idea of this regime? Despite its importance, historians are vague in this regard. Perhaps this imprecision finds its roots in the understanding by historians that, here, Bolivar makes a qualitative leap forward with respect to the ideas he borrowed or because the documents of the time did not provide sufficient information. To answer this question, in the first part we define the amphictyonic notion in the Jamaica Letter, then, we trace the specific sources used as a model, and to conclude, we identify common elements of the Bolivarian Project and the confederal tradition.

\section{The Bolivarian conception}

Bolivar refers to the Greek amphictyony and to the project of the abbot Saint-Pierre in the same paragraph of the Letter: ${ }^{2}$

It is a grandiose idea to think of consolidating the New World into 
a single nation, united by pacts into a single bond. It is reasoned that, as these parts pave a common origin, language, customs, and religion, the ought to have a single government to permit the newly formed states to unite in a confederation. But this is no possible. Actually, America is separated by climatic differences, geographic diversity, conflicting interest, and dissimilar characteristics. How beautiful it would be if the Isthmus of Panamá could be for us what the Isthmus of Corinth was for the Greeks! Would to God that some day we may have the good fortune to convene there an august assembly of representatives of republics, kingdoms, and empires to deliberate upon the high interests of peace and war with the nations of the other three-quarters of the globe. This type of organization may come to pass in some happier period of our regeneration. But any other plan, such as that of Abbé St. Pierre, who in laudable delirium conceived the idea of assembling a European congress to decide the fate and interests of those nations, would be meaningless (BOLÍVAR, 1964, v. II, p. 215-235).

It should be noted that these references came after the earlier notion of confederate union. In the article published in 1810 in the Morning Chronicle of London, where he goes in search for help for the young Venezuelan Revolution, Bolivar predicts that after independence, the government of Venezuela will invite all American governments to unite under a confederal system and that they, "already prepared for such a project, will hastily follow the example of Caracas". ${ }^{3}$ The prolongation of the War of Independence postpones the ecumenical plan until 1818, when Bolivar writes to the Director of the United Provinces of the Río de la Plata, Juan Martín Pueyrredón, to propose the formation of a "political body" comprising the states of the former Spanish America. ${ }^{4}$ In 1821, after the approval of the Constitution of Colombia, Bolivar and Pedro Gual draft the treaty through which the Hispanic Americans will integrate

Between 1822 and 1825, four treaties of confederal union were signed with Peru, Chile, Mexico, and Central America. The treaty negotiated in Mexico by Miguel Santamaría and Lucas Alamán, acts on minor changes to Bolivar's draft and serves as a good example of the Bolivarian conception. According to its Art. 1, both countries decide to join, unite and federate "to support their independence and ensure their mutual prosperity"; Art. 2 states that border delimitations depend on their situation "prior to the war" (uti possidetis); in Art. 10, the countries commit to make common cause against foreign enemies; and Art. 12, which is key to this type of regime, defines the representation in the assembly:

To strengthen the ties that in the future must unite both States and to overcome any difficulty that may arise and disrupt their good correspondence and harmony, an assembly composed of two plenipotentiaries of each party will be formed on the same terms and with the same formalities in accordance with the usages established for the appointment of ministers of the same class near the governments of foreign nations (REZA, 2010, p. 31).

The amphictyonic model is endorsed by Art. 17, which establishes that the perpetual confederation pact "shall not interrupt in any manner the exercise of national sovereignty" (REZA, 2010, p. 32). "It is not a defensive and offensive alliance", such as those organized in 
Europe at the time, but "a society of sister-nations". The circular accompanying the draft insists on this point and endows it with a Rousseauian quality by defining the Confederation as "the foundation of the social pact that should form a Nation of Republics of this world". ${ }^{5}$

Comparing its wording with the characteristics of the Greek amphictyony (described in the next sections of this paper), five common elements stand out:

(1) Member states are obliged to resign extralegal recourses;

(2) The defensive and offensive alliance will protect each member's independence;

(3) Disputes will be settled through arbitration;

(4) The General Assembly will address the current affairs of the Confederation; and

(5) Borders will be inviolable and will take the existing boundaries as the point of departure (in the case of Greece) or the administrative borders of the colony before the beginning of the War of Independence (1810, in the Hispanic-American case).

The differential elements are no less, although their importance lies in the fact that they respond to American characteristics and needs: the granting of trade preferences, the abolition of slavery, the independence of Cuba and Puerto Rico, the design of the rights of foreign consuls, the rejection of the European proposal to buy diplomatic recognition, ${ }^{6}$ the organization of the confederate army, the functioning of the assembly, and others. These elements are described by military, confederal, and commercial codes that will last beyond the cancellation of the Bolivarian initiative in 1828 , while serving as guides to subsequent confederal initiatives in 1847-48, 1856, and 1865-66. ${ }^{7}$

\section{Works consulted on amphictyony}

On what sources does Bolívar base the essential components of confederal unionism? The article in the Morning Chronicle reminds the manifesto juntista of April 27, 1810, in which the Caracas elite invited American juntas to "uphold the same principles of autonomy and to promote the great work of the Spanish-American Confederation". The Jamaica Letter, on the other hand, involves resorting to sources on the Amphictyonic regime and Saint-Pierre's project. In America, there are very few documents that could have informed Bolivar on these issues: the plans of Juan Egaña, studied in the first chapter of this book, unknown to him; a text by Fray Servando Teresa de Mier; and an essay of The Federalist. In the Second Letter from an American to El Español in 1812, Mier seems to anticipate the general features of the Bolivarian project:

A Congress, therefore, next to the Isthmus of Panama, sole arbitrator of peace and war across the Colombian continent, would not only contain the ambition of the Principino of Brazil and the claims of the United States but that of all Europe [...]. The misfortunes of the old world should give these lessons to the new one, where they are only practicable due to the homogeneity of language, education, customs, religion, and laws (MIER, 1987, p. 41). 
There is no doubt that Bolivar consulted this text: in his Letter, he quotes a certain (José) "Guerra", the pseudonym used by Mier to publish in 1813 the Historia de la Revolución de la Nueva España [History of the Revolution of the New Spain]. The Federalist is an interesting source due to its criticism of the laxity of the confederal regime, favoring a more centralist positions. Hamilton, Madison and Jay (2001, p. 69-73) use this opinion to propose the reform of the first Constitution of the United States and the adoption of a federal system with a central administration and several state governments. ${ }^{8}$

Here, it should be admitted that both documents, the Carta of Mier and The Federalist, are insufficient to fully define amphictyony and that we must turn to Bolivar's classical readings. As we all know, the best references on the amphictyonic leagues are the works by Polybius, Thucydides, Herodotus, Aeschines, Aristophanes, Strabo and Demosthenes. Except for the first, none of these authors appears in the Bolivar's library and lists of readings, ${ }^{9}$ although he referrers to works that incidentally address the topic of leagues: On invention. The best kind of Orator by Cicero (1949, p. 33, 69, 73, 180, 247 and 248), the Annals by Tacitus (1937) and the Parallel lives of noble Grecians an Romans by Plutarch (1967), who refers to amphictyony in the biographies of Cimon, Demetrius, Lisandro, Solon, Sila and Themistocles, almost always as context.

That said, Polybius authored the best historical account on the amphictyonic league: in 14 of the 39 books that compose his Histories, he reviews the evolution of the Hellenic confederations, particularly the Achaean League based in Corinth. ${ }^{10} \mathrm{It}$ is not known which editions were read by Bolivar, although in his time, The Histories, translated into Spanish by A. Rui Bamba and published in three volumes in Madrid in 1789, and a French version in six volumes, first edited by Gandouin in 1727-1730 and then by Merkus in 1774, were available. Bolivar also holds an Ancient history in 13 volumes with no mention of the author (PÉREZ VILA, 1964), although by its subject matter and its dimensions, we can assume that it included a wealth of information regarding the Greek League.

In addition to the classical literature, we should consider the books on political philosophy that Bolivar cited or that are found among his belongings. Observations sur l'histoire de la Grèce [Comments on the history of Greece] is significant for our analysis. It was published in 1749 by Gabriel de Mably, the same person who later advised Rousseau on the suitability of synthesizing the works of Saint-Pierre. In this book (1749, p. 10-11 and 12-18), he defines Greek amphictyonies as a pact between "love for independence" of the city-states and the need to protect themselves through "a powerful and respected body". If Bolivar payed attention to that paragraph, which contains the main basis for the Amphictyonic model, then he may have seen reflected in it his desire to reconcile the sovereign zeal of the Hispanic American colonial centers with the aim of protecting them through the union of their army and foreign policies.

\section{On the abbot Saint-Pierre}


Let us review the Bolivarian reception of Saint-Pierre's project, important despite the fact that there are fewer clues on this relationship. According to Bolivar, his best-known French thinkers include Voltaire, Rousseau, Locke, Condillac, Bufón, D'Alambert, Helvetius, Montesquieu, Filangieri, Lalande, Rollin, and Berthot in addition to Mably. ${ }^{11}$ Of these authors, the only ones who refer to Saint-Pierre are Voltaire and Rousseau (See Table 1). Voltaire represents a problematic source. His celebrated Le Siècle de Louis XIV [The Age of Louis XIV] of 1751, exempts the absolutist monarch from Saint-Pierre's recommendation (included in Discours sur la Polysynodie from 1719), according to which kings must make their decisions based on the advice of a group of experts and not on their sole discretion. In the following writings, Voltaire refers to the Projet pour rendre la paix perpétuelle en Europe [Project for Perpetual Peace], from critical positions and in a satirical tone.

These references appear in his Extrait d'une lettre sur une coutume très utile établie aux Pays-Bas [Excerpt from a letter on a very useful custom established in the Netherlands], from 1739; the Réécrit de l'Empereur de la Chine à l'ocassion du projet de paix perpéuelle [Rescript of the Emperor of China on the Occasion of the Plan for Perpetual Peace], from 1761; the "Chinese Catechism" from the Philosophical Dictionary of 1764; the Lettres à S.A. Mgr. Principe de... [Letters to S.A. Mgr. Prince of...], published in 1767; Le dîner du comte de Boulainvilliers [The Count of Boulainvilliers' dinner], 1767; Fragment sur l'histoire générale [Fragment on General History], 1773; one of the epigrams included in Poésies mélangées [Miscellaneous French poems]; and in the opuscule Sur la paix perpétuelle du docteur Good-heart [On the perpetual peace of the doctor good-heart], of 1769.12

The Rescript puts in the mouth of an imaginary Eastern dignitary a suggestive objection to the eurocentrism of the Project:

\footnotetext{
We have attentively read the pamphlet of our beloved Jean-Jacques, citizen of Geneva, which Jean-Jacques has written the abstract of a Plan of Perpetual Peace by the bonze Saint-Pierre, which bonze Saint-Pierre had abstracted it from a clerk of the mandarin marquis de Rosny, Duke de Sully, an excellent economist, who had abstracted it from the depth of his brain We have been keenly afflicted to see that in the said abstract edited by our beloved Jean-Jacques, where are set out the easy means for giving Europe a perpetual peace, the remainder of the Universe - which must always be in view in all these pamphlets - has been forgotten. We knew that the monarchy of France, which is the foremost of monarchies; the anarchy of Germany, which is the foremost of anarchies; Spain, England, Poland, Sweden, which are, according to their historians, each in its kind, the foremost power of the universe, are all required to accede to the treaty of Jean-Jacques. We have been edified to see that our dear cousin the empress for all Russia was similarly required to furnish her contingent. But great was our imperial surprise when we searched in vain for our name in the list. We judged that, being such a near neighbor of our dear cousin, we should have been named along with her; that the Great Turk neighbor of Hungary and of Naples, the king of Persia, similarly have the same rights, and that it would be doing a flagrant injustice to Japan to forget it in the general confederation (ROUSSEAU, 2005, p. 50).
} 
This work is a reaction to the summary of the Projet published by Rousseau in 1761, which he knows all too well: a copy of it was found in his private library at Ferney, now located in the National Library of Russia in St. Petersburg. Next to the paragraph in which the symbiosis Rousseau-Saint Pierre argues in favor of a European Confederation able to change the state of war that prevails among the countries of the continent into an "eternal peace", Voltaire notes: chimeric (HAVENS, 1966, p. 35). He doesn't know it, but also Rousseau believes Saint Pierre's plan is utopian. Instead of a single work on the Projet, Rousseau writes first the summary (Extrait) in which he expresses Saint Pierre's ideas as if the abbot himself had defended them, and then a critical piece (Jugement), where he displays an opposite point of view.

The Jugement was published after Rousseau's and Voltaire's death in $1778 .{ }^{13}$ His main criticism points to "the principle of perfected reason" that underlies the Saint Pierre's proposal, which he considers false. Although he refrains from adjectivizing the work of chimeric, it is not far from doing so:

Thus, although the project was very wise, the means of executing it were influenced by the simplicity of the author. He thought that it was only necessary to assemble a congress, to propose its articles, to sign them, and everything was done. Let us agree that in all the projects of this honest man he saw the effect of things well enough when they were established, but he judged as a child the means of establishing them (ROUSSEAU, 1817, p. 447).

Moreover:

No doubt perpetual peace is by now an absurd project. But give us a Henri IV and a Sully [the proponent of the first plan of European Confederation], perpetual peace will become a reasonable project: or rather, let us admire a beautiful plan, but let us console ourselves for its non-realization, because this can be done only by violent and formidable resources (ROUSSEAU, 1817, p. 62).

Back to Voltaire, it should be said that even though Bolivar knew his satires, his own attitude towards Saint-Pierre's plan suggests that the Venezuelan never considered them seriously. The key source and perhaps Bolivar's only source is precisely the Extract in which Rousseau presents the ideas of Saint-Pierre in an attractive and compelling manner. This conclusion overlaps his well-known fondness for the Swiss philosopher, preferred above all others of his time (MIRAMÓN, 1959, p. 14-16), and the similarities between the "five fundamental articles" that synthesize Saint-Pierre's doctrine (ROUSSEAU, 1817, p. 416-418) and the Bolivarian confederal treaty:

(1) According to the first article, the governments should institute a perpetual and irrevocable alliance, with an assembly in which plenipotentiaries would meet and conflicts among members would be solved by arbitration or trial.

(2) The second relates to the functioning conditions of the diet, which determine which countries would be invited to join the confederation and which would be common expense contributions. 
(3) The third guarantees the integrity of member countries, and to that end, it takes the treaties and boundaries in force as its basis.

(4) The fourth specifies the sanctions for the violators of confederal law, including the lifting of a confederal army.

(5) The fifth and final article gives the plenipotentiaries the authority to create regulations for the confederation, although it prohibits any change in the fundamental articles.

\section{A dark reception}

Did Bolivar know of Saint-Pierre's plan first hand, as suggested by some historians? Clearly, it must be said that he did not lack opportunities to consult the original. Before his stay in Paris between 1804 and 1806, the literary salons commented on, among other issues, Saint-Pierre's "utopia" and his expulsion from the French Academy. In 1810, he went to the library of Francisco de Miranda, who in 1780 had acquired a copy of Annales politiques [Political annals] by Saint-Pierre (MIRANDA, 1982, p. 29; USLAR PIETRI; GRASES, 1979), a work less known than the Polisinodia or the Project. However, there is no evidence to support this hypothesis. In fact, there are several indications that point to the contrary. The most important is that there is no registered copy of the work in Hispanic America before 1815. The second is its poor dissemination, due to several reasons:

(1) Tts cumbersome and difficult-to-understand style;

(2) The editorial strategy of Saint-Pierre, who used to send 30 copies to print and, after collecting readers' views, proceeded to a new print;

(3) The difficult travel to Hispanic America, where the works of the Enlightenment arrived through travelers who placed them in private libraries, thus limiting their dissemination;

(4) The edicts from 1756 and 1764, which vetoed, in totum, the Discourse on Inequality and The Social Contract.

The inquisitorial interdictions were not rhetorical; they led to the imprisonment of some of its readers, as was the case with Camilo Henriquez during its formative stage in Lima (SILVA CASTRO, 1960, p. 60). That said, it is possible that the historians have mistaken Rousseau's Extract and Saint-Pierre's Project. The Miscellaneous Works by Rousseau, published in Amsterdam in 1761, include the Extract without clarifying that it follows the work of another author (FERRARI, 1997, p. 28). Dreams of an Honest Man, an anthology of the work of Saint-Pierre (1775, p. 171-194) does not mention the Project of Perpetual Peace; rather, it publishes parts of the Extract with a footer. In these conditions, it is not surprising that students of Bolivar's work could not specify the consulted version of the Project (PÉREZ VILA, 1964, p. 443). 


\section{By way of conclusion}

The preceding sections have aided in the justification of the hypothesis that Bolivar knew from good sources the history of the Greek League and was aware of Saint-Pierre's project, particularly owing to Rousseau's Extract. From this perspective, Bolívar's ecumenical conception and its components, particularly the commercial, military and confederal codes, constitute a personal recreation of the intellectual tradition of amphictyonies. The originality of the transfer to Hispanic America is reflected not only in the characteristics of the project but also in the consistency that it gives to the entire independence enterprise.

In a conceptual sense, the amphictyonic plan represents the common thread that binds the Letter of Jamaica to the creation of Colombia, the Colombian Constitution of 1821 to the bilateral treaties of confederation and them to the Congress of Panama. Thus, the Jamaica Letter is not only a reflection on the crucial moment that presents the extinction of the old Spanish colonial structure to the world but also the framework for the definition of a law of "sister-nations" capable of uniting their forces without interfering in their domestic affairs. In other words, the amphictyonic confederation represents a time, a programmatic component of the independence, and the source of viability for the Hispanic American republics.

Table 1 -Sources on the Amphictyonic league, and Saint Pierre's Plan of confederacy (available before 1815)

\begin{tabular}{|c|c|}
\hline $\begin{array}{l}\text { On the amphictyonic league } \\
\text { - Polybius, Histories } \\
\text { - Thucydides, The war of the Peloponnesus } \\
\text { - Herodotus, Historiae } \\
\text { - Aeschines, Fraudulent Embassy } \\
\text { - Aristophanes, Lysistrata } \\
\text { - Strabo, Geography } \\
\text { - Demosthenes, Political speeches }\end{array}$ & $\begin{array}{l}\text { On the Project for Perpetual Peace } \\
\text { - Saint Pierre, Projet de paix perpétuelle } \\
\text { - Jean Jacques Rousseau, Extrait du Projet } \\
\text { - Voltaire, several works }\end{array}$ \\
\hline $\begin{array}{l}\text { Simon Bolivar's readings on both } \\
\text { subjects } \\
\text { - Polybius, Histories } \\
\text { - Cicero, De Inventione } \\
\text { - Tacitus, Annals } \\
\text { - Plutarch, Parallel lives } \\
\text { - ¿? Ancient History } \\
\text { - Gabriel de Mably, Histoire de Grèce } \\
\text { - Alexander Hamilton et alii, The Federalist } \\
\text { - Jean Jacques Rousseau, Extrait } \\
\text { - Voltaire, several works }\end{array}$ & $\begin{array}{l}\text { Mentioned in Hispanic America } \\
\text { - Juan Egaña, Dieta sudamericana } \\
\text { - Servando Teresa de Mier, Cartas }\end{array}$ \\
\hline
\end{tabular}




\section{References}

BOLIVAR, Simon. Cartas del Libertador. I-VII. Caracas: Banco de Venezuela and Fundación Vicente Lecuna, 1964-1970. 7. v.

BOLIVAR, Simon. The Political Thought of Bolivar: Selected Writings. Edited by G. Fitzgerald. The Hague: Martinus Nijhoff, 1971.

CICERO, Marcus Tullius. On Invention. The Best Kind of Orator. Topics. Cambridge: Loeb Classical Library, Harvard University Press, 1949.

FERRARI, Jean. L'abbé de Saint Pierre, Rousseau et Kant. In: LABERGE, P.; LAFRANCE, G.; DUMAS, D. (Ed.). L'année 1795: Kant, essai sur la paix. Paris: Librairie J. Vrin, 1997. p. 25-40. HAMILTON, Alexander; MADISON, James; JAY, John. The Federalist (1780). Traducción de G. R. Velasco. Indianapolis: Liberty Found, 2001.

HAVENS, George R. Voltaire's Marginalia on the Pages of Rousseau: A Comparative Study of Ideas. New Yok: The Ohio State University, 1966.

MABLY, Gabriel Bonnot de. Observations sur l'histoire de la Grèce. Ginebra: Compagnie des libraires, 1749.

MENDOZA, Cristobal de; YANES, Francisco. Documentos importantes relativos a la vida del Libertador de Colombia y del Perú. Appendix, Caracas: Imprenta de Damirón y Dupuy, 1833. v. XXI.

MIER, Fray Servando Teresa de. Cartas de un americano 1811-1812. Mexico: Secretaría de Educación Pública, 1987.

MIRAMÓN, Alberto. Los libros que leyó Bolívar. Bogotá: Publicaciones de la Asociación Colombiana de Bibliotecarios, 1959.

MIRANDA, Francisco de. América espera. Caracas: Fundación Biblioteca Ayacucho, 1982.

O'LEARY, Daniel Florencio. Memorias del General O'Leary, I-XXXIV. Caracas: Ministerio de la Defensa de Venezuela, 1981.

PÉREZ VILA, Manuel. La formación del Bolívar: estudios y lecturas. Caracas: Sociedad Bolivariana de Venezuela, 1964. 
PERKINS, Merle L. Voltaire and the Abbé de Saint Pierre. The French Review, v. 34, n. 2, p. 152-163, 1960.

PLUTARCH, Lucius Mestrius. Plutarch's Lives. Cambridge: Loeb Classical Library, Harvard University Press, 1967. v. I, III, IV and VII.

POLYBIUS. The Histories. Cambridge: Loeb Classical Library, Harvard University Press, 2010. v. I-III.

REZA, Germán A. de la. Documentos sobre el Congreso anfictiónico de Panamá. Caracas: Biblioteca Ayacucho, 2010.

REZA, Germán A. El ciclo confederativo: Historia de la integración latinoamericana en el siglo XIX. Lima: Universidad Nacional Mayor de San Marcos, 2012.

ROUSSEAU, Jean-Jacques. Jugement sur la Paix Perpétuelle. In: ROUSSEAU, JeanJacques. Euvres de J.J. Rousseau. Paris: Imprimerie de P. Didot l'Ainé, 1817. v. II, p. 48-62.

ROUSSEAU, Jean-Jacques. The Plan for Perpetual Peace, on the Government of Poland, and other writings on History and politics. New Hampshire: University Press of New England, 2005.

SAINT PIERRE, Charles Irénée Castel de. Les rêves d'un homme de bien, qui peuvent être réalisés; ou les vues utiles et pratiquables de M. L'Abbé de Saint-Pierre, choisies dans ce grand nombre de Projets singuliers, dont le bien public étoit le principe. Paris: La Veuve Duchesne, 1775.

SILVA CASTRO, Raúl. Escritos políticos de Camilo Henríquez. Santiago: Ediciones de la Universidad de Chile, 1960.

TACITUS, Publius Cornelius. Annals. Cambridge: Loeb Classical Library, Harvard University Press, 1937.

USLAR PIETRI, Arturo; GRASES, Pedro. Los libros de Miranda. Caracas: La Casa de Bello, 1979.

VOLTAIRE, François-Marie Arouet. Euvres complètes. Kehl: Société Typographique, 17841789.

WALLEZ, Jean Baptiste. Précis historique des négociations entre la France et Saint-Domingue, suivi de pièces justificatives. Paris: Ponthieu, 1826. 


\section{Notes}

1 Vicente Lecuna lists the following versions: Austria, Larrazábal, Blanco and Azpurua, O'Leary, and Mendoza and Yanes. The latter was edited in Bolivar (1964, p. 215-235). According to Lecuna, Briceño Méndez gave the original to Yanes at the time he was publishing the XXI volume. After this publication, the historian Guillermo Hernández de Alba sent to Lecuna an older version. This version is in the General Archive of Bogotá. Clearly, this is the English version, which was completed two weeks after the Spanish version of the Jamaica Letter.

2 For this study, two different versions of the "Reply of a Southern American to a gentleman of this Island" have been used: that by Daniel F. O'Leary (1981, I, p. 69-95) and that which appears contained in Cartas del Libertador [Letters of the Liberator] (BOLIVAR, 1964, v. II, p. 215-235). For the English translation, see: Bolivar (1971, p. 41).

3 Bolivar, "Carta de un español de Cádiz a un Amigo suyo en Londres", Morning Chronicle, London, September $5,1810$.

4 Bolivar to Juan Martín Pueyrredón, Angostura, June 12, 1818 (BOLIVAR, 1964, v. II, p. 19).

5 Bolivar to Supreme Director of Chile, to Peru's Protector, and to Supreme Director of Buenos Aires, Cali, January 9, 1822 (BOLIVAR, 1965, v. III, p. 181-184).

6 Shortly before the Panama Congress, Haiti "buy" the diplomatic recognition of France for the astronomical sum of 150 million francs, later reduced to 60 million. The conditions imposed to Haiti by the Ordinance signed by King Chales $X$ of France in the Castle of the Tuileries on April 17, 1825 include, in addition to the monetary compensation, the reduction by half of the tariffs charged to other foreign merchants. "Ordonnance du roi", Paris, 1 April 17, 1825 (WALLEZ, 1826, p. 442-443).

7 The confederal project reborn in January 1831, weeks after the death of Bolivar. The Mexican Chancellor, Lucas Alaman, sends its representatives to Central and South America in order to reinstall the Congress of Tacubaya and continue the creation of the Confederation. The delegates finally gather in Lima in early 1847, and like the Congress of Panama, the Congress of Lima fails to implement the unity for lack of ratification of the treaties. The next unionist initiative, seeks to respond to the expansionist policy of United States. The Continental Treaty signed in 1856 proposes a system of protection based on the same idea of a confederate defense. Hispanic Americans still organized a conference in the capital of the Peru in 1865, frustrated by the political immaturity of the parliaments. After this effort, the confederate movement ceases when burst the first wars of conquest between Latin American countries: the War of the Triple Alliance and especially the War of the Pacific. The latter involved the countries that had hosted three amphictyonic conferences (REZA, 2012).

8 A copy of this work is in the list of "Cargas de papeles y efectos" of Bolivar [Bolivar's papers and effects] taken out of Popayán in December, 1827. Cf. National Archive of Colombia, "Peticiones y Solicitudes", La República, volume XVII, folios 312-314.

9 However, this absence does not imply that he did not know about them. His first education (directed by Simón Rodríguez and, to a lesser extent, by Andrés Bello) includes the classics of antiquity, Spain, France, Italy, and England. Bolívar to Francisco de Paula Santander, Arequipa, May 20, 1825 (BOLIVAR, 1966, v. IV, p. 330).

10 Besides being the main historian of the last Hellenic League, Polybius is the most important source of the defeat of Carthage at the hands of Scipio the African. Polybius (2010, II 2-4, 45; IV 6, 9, 16, 25, 26, 27, 30, 61, 62, 63, 64, 65; V 5, 6, 14, 26, 27, 96, 97, 102, 107; IX 32-40, 41-42; XI 5, 4, 7; XIII 3; XVI 24; XVIII 2, 3, 10, 38, 46, 47; XX 4, 5, 9-11; XXI 25, 32; XXIII 18; XXVII 15; XXVIII 4; and XXXIX 1).

11 However, it does not specify the works consulted. Bolivar to Francisco de Paula Santander, Arequipa, 20 de mayo de 1825 (BOLIVAR, 1966, v. IV, p. 345).

12 Voltaire (1784-1789). The criticism of Voltaire reached its peak after the publication of the abstract by Rousseau. This does not prevent him from praising Saint-Pierre's critique of the superstitions of the time and his study of French tax revenue. The comments and opinions of Voltaire concerning the abbot have been studied by Perkins (1960, p. 152-163).

13 In July of this year, Caterina II of Russia acquired the entire library of Voltaire. The marginal notes to the works of Rousseau are numerous and critical, leaving no doubt about his little sympathy for the "citizen of Geneva". 
Germán A. de la REZA. Professor da Universidad Autónoma Metropolitana (UAN), no México. Doutor em História e Filosofia pela Université de Toulouse - Le Mirail e Doutor em Ciências Econômicas pela Université Paris I - Panthéon-Sorbonne.

Recebido em: 20/05/2017

Aprovado em: 18/09/2017 